NBER WORKING PAPER SERIES

\title{
INTEGRATED POLITICAL STRATEGY
}

John M. de Figueiredo

Working Paper 15053

http://www.nber.org/papers/w15053

\author{
NATIONAL BUREAU OF ECONOMIC RESEARCH \\ 1050 Massachusetts Avenue \\ Cambridge, MA 02138 \\ June 2009
}

The views expressed herein are those of the author(s) and do not necessarily reflect the views of the National Bureau of Economic Research.

NBER working papers are circulated for discussion and comment purposes. They have not been peerreviewed or been subject to the review by the NBER Board of Directors that accompanies official NBER publications.

(C) 2009 by John M. de Figueiredo. All rights reserved. Short sections of text, not to exceed two paragraphs, may be quoted without explicit permission provided that full credit, including $\odot$ notice, is given to the source. 
Integrated Political Strategy

John M. de Figueiredo

NBER Working Paper No. 15053

June 2009

JEL No. K23,P16

\section{ABSTRACT}

This paper reviews the literature on corporate political strategy and identifies a number of open research questions and streams for potential investigation. The paper develops a framework to explain why, when, and how a firm will pursue multi-forum political action as part of its non-market and integrated strategy.

John M. de Figueiredo

Anderson School of Management

UCLA

Cornell Hall D508

110 Westwood Plaza

Los Angeles, CA 90095-1481

and NBER

jdefig@anderson.ucla.edu 


\title{
Integrated Political Strategy
}

\author{
John M. de Figueiredo
}

30 March 2009

\section{Introduction}

In 2000, as the Occupational Safety and Health Administration (OHSA) was about to deliver its new rules regarding ergonomics standards, the United Parcel Service (UPS) mobilized into action. For 10 years UPS had vociferously opposed the development of rules regarding these standards for business, arguing that it is difficult to make uniform ergonomic rules for diverse production and business processes. This fight at OSHA had included tens of thousands of pages of evidence, data, and detailed commentary. Simultaneously, UPS had waged a war on the potential regulations in Congress. UPS had contributed to legislator campaigns, becoming one of the largest political action committee (PAC) contributors to federal candidates. In addition, the company spent millions of dollars lobbying (providing information to) legislators. Concurrent with all of these actions, UPS unleashed a brigade of attorneys to fight the proposed regulations in the U.S. Federal Courts. By early 2001, UPS and the business lobby prevailedin Congress. They successfully lobbied Congress to pass legislation that halted the implementation of any OSHA ergonomic standards.

Every year, the U.S. government establishes thousands of laws, rules, and regulations that affect the competitive landscape. Indeed, in many ways, these rules are the competitive landscape on which firms compete. Traditional competitive strategy tools have dedicated themselves to analyzing how firms gain competitive advantage in markets. Whether industry-driven, resource-based, technology-focused or network-centric, the tools and theories of strategic management focus on how firms gain competitive advantage over their rivals when the landscape is exogenously given.

Non-market strategy, however, assumes that this landscape for pricing, investment, and competition decisions is not exogenous. Rather, it explicitly considers the landscape as endogenous—a landscape that a firm can affect with various tools at its disposal. This landscape can be created, tilted, or altered to give one firm the high ground and another firm the low ground (Stigler 1971, Peltzman 1976, 
Becker 1983). One way to do this is through corporate political strategy. Corporate political strategy addresses how a firm interacts with political institutions to change the competitive landscape and obtain competitive advantage. ${ }^{1}$

This is a growing area in strategic management. Legal and acceptable competitive behavior is determined endogenously by legislators, regulators and judges who are influenced, positively and negatively, by the very same firms the regulations are designed to control. By understanding the theories of how firms affect politics, one can better determine how to gain competitive advantage through political institutions. This is a natural extension of the traditional tools of strategic management. Moreover, for young scholars, this is an area in which the lines of investigation are clear and the openings for serious research opportunities available. In this sense, it is robust area for future research and major contributions to understanding firm performance.

This paper begins by providing an organizing framework for thinking about corporate political strategy and firm profitability. It then provides an overview of the work that has been done in the area and highlights the open research areas and research questions that scholars might examine going forward. Some concluding thoughts are provided at the end.

\section{A Framework for Integrated Political Strategy}

In the United States, and almost every democratic country in the world, there are three primary levels of policy-making: legislatures, agencies, and courts. The organizing framework begins with these three institutions.

The legislature is charged with creating statutes that govern society. Given its wide latitude in creating rules, the legislature can create laws that affect a range of economic activity. The first way the legislature affects economic activity is through its own participation in the buyer-supplier relationship. The legislature has the power to tax and use those monies for transfers or procurement. In the United States, the federal government budget is \$3.1 trillion (Executive Office of the President, 2008). As such,

\footnotetext{
${ }^{1}$ Some have suggested this is merely raising rival's costs (Salop and Scheffman 1983), but as will be evident from
} 
the Congress can allocate resources through the taxation, budgeting, and appropriations process, to substantially affect the composition of economic activity. For firms, this means that the governmental allocation of monies can affect the profitability of not only the industry in which the firm competes, but it may also have particularized benefits to the firm itself, as in the allocation of money to certain firms for goods and services provided (fighter jets, roads, information technology systems).

Perhaps a more powerful mechanism by which the legislature affects firms is through the regulation of specific economic activities. In nearly every area of the economy, Congress has the ability to create legislation that determines the rules by which companies compete. These include antitrust regulations, intellectual property rules, and safety rules. In addition, the legislature creates numerous industry-specific regulations in telecommunications, energy, banking, and health care, to name just a few.

Because legislatures have such wide latitude in creating laws, they are expertise- and timeconstrained in detailing and implementing the rules. Thus, legislators often delegate the details of rulemaking to a second institution, administrative agencies, such as the Federal Communications Commission (FCC), the Environmental Protection Agency (EPA), the Federal Energy Regulatory Commission (FERC), and the Securities and Exchange Commission (SEC). Indeed, there are over 100 government agencies in the U.S. that are charged with implementing rules. Although only Congress can create statutes, these administrative agencies can create rules, regulations, and findings, through various procedures, with the "force of law” (Strauss et al, 1995: Chapter 1). Every year, each agency creates thousands of rules and makes thousands of determinations that have a significant impact on business (de Figueiredo and Tiller, 2001). Verizon cannot enter certain markets without the permission of the FCC. General Electric must obtain a ruling from the SEC or IRS to make certain financial accounting and disclosure changes. Pacific Gas and Electric (PG\&E) must obtain permits from the EPA before it can construct a new power plant. The ability of agencies to engage in rulemaking and adjudication makes agencies perhaps the most intrusive, if not important, governmental player in the day-to-day operations of firms.

this literature, integrated political strategies go far beyond this phenomenon. 
A final rule-making body is the courts. Businesses and interest groups that are dissatisfied with an administrative agency's rules can choose to challenge those rules in courts. Courts have shown a willingness to overturn agencies (Schuck and Elliott 1990) and in many cases, create new policies that affect business. Although courts have not traditionally been thought of as a "policymaking” branch of government, it is clear they engage in this activity. Courts determined that foremen are workers and not management, and thus eligible to unionize and engage in collective bargaining (Bell Aerospace Co, v. NLRB, 1974); courts intervene in the making of environmental policy and the emission of stationary sources of pollution (Chevron v. Natural Resources Defense Council 1984); and courts put their stamp on tariff rates and product classifications (U.S. v. Mead 2001). Courts, through their ability to overturn agencies, and their proclivity to create new policy, can have a large impact in the rules that affect business.

Given that legislatures, agencies, and courts are the governmental actors, we now must understand two additional aspects to the policy-making process to make sense of the way these actors pursue policy: the order of action and the role of interest groups. ${ }^{2}$ The first important aspect to policymaking is the order of action. Congress generally moves first, setting up broad legislation, which provides a general guide for business activity. Congress then delegates authority to agencies to implement the guidelines. Administrative agencies, with accumulated experience in the field, then enact regulations under the watchful oversight of Congress. Firms and interest groups that dislike the rulings can choose to challenge the agency’s ruling in court. In general, the policy-making actors act sequentially. ${ }^{3}$

A second important aspect to policy-making is that it does not happen in a vacuum. Interest groups such as firms and unions constantly try to influence the outcome of policy. Just as firms compete in the market, they also compete in the political arena, attempting to influence the outcome of the rules of market competition to enhance their profitability. One way firms pursue profit is through market competition, such as the introduction of new products or pursuit of certain pricing or acquisition

\footnotetext{
${ }^{2}$ We discuss the utility function of these political actors in the next section.

${ }^{3}$ The different government institutions do not necessarily have to act sequentially, but frequently they act in the manner described in this paper.
} 
strategies. A second way firms pursue profits is through the political sphere, winning the non-market competition in the political arena so that political actors create rules which enhance the profitability of the firm either directly (through subsidies, tax breaks, and the like) or indirectly (through the creation of regulations which will enhance the profitability of the firm). This is the essence of nonmarket strategy (Baron 2002, Spulber 1994).

Figure 1 illustrates a framework for nonmarket strategy. The top of the figure has the interests groups that provide inputs into the political sphere. The inputs come in two main forms-money and information. This money and information is provided to the three main political actors who deliver rules and policies: legislatures, agencies, and courts. These actors are placed in the sequential order in which they can deliver rules, with the legislature first, the administrative agency second, and the courts third. In turn, these actors create policy. These policies become the "rules of the game” that firms compete under. Thus, in each political forum, the firms compete to obtain policy.

\section{***INSERT FIGURE 1 ABOUT HERE***}

Figure 1 illustrates three main ideas. The first is policy-making is generally, but not always, sequential across political institutions. Second, there are multiple forums in which firms and interest groups can create and block policy. Finally, firms compete in two markets, the product market and the political market. We call the unified non-market and market strategies the integrated strategies of the firm. With this as the general framework, an analysis of the political strategy of firms can be completed.

\section{Instruments of Political Strategy}

In each forum, the two main instruments at the disposal of firms to influence policy-making are money and information. The use of these instruments is integral to the strategy of the firm because politicians and policy-makers are responsive to these instruments. Just as investments are made by firms in plant, equipment, and brands, so, too, are investments made by firms in money and information to affect the political landscape (Snyder 1990, 1992). Frequently, very senior executives are involved in this 
investment process. In this section, we consider the role, influence, and effectiveness of money and information in each institution.

\section{A. Legislatures}

\section{Money}

A legal form of money transfers from firms to legislators comes in the form of campaign contributions. ${ }^{4}$ Candidates require money to run their (re)election campaigns. While some money may come from the State and other money from individuals, in many countries, money contributions from firms and other interest groups is permissible. There is a substantial debate in the literature as to the effect of this money. The most common theoretical models view these transfers as having the same effect as bribes. In most of the "vote-buying” models, firms, unions, and industry associations contribute money to legislators to change the vote, or "buy the vote,” of the legislator on a particular bill (e.g. Snyder 1991, Grossman and Helpman 1994, Groseclose and Snyder 1996, Besley and Coate 2001). Empirical work on vote buying is mixed. There have been dozens of papers in economics and political science that have attempted to estimate the effect of (PAC) campaign contributions on votes. The prevalent empirical view until about five years ago was that money transfers significantly influenced vote outcomes. (See, for example, Stratmann 1992, 1998, Goldberg and Maggi 1998). However, Ansolabehere et al (2003) conducted a comprehensive overview of the empirical literature on votebuying, summarizing the results of all empirical papers in economics written during the previous 30 years. They highlight that a systematic problem in the empirical literature is that many papers that conduct econometric tests of vote-buying are misspecified. The traditional approach in these papers is to use the legislator's vote as the left hand side variable and campaign contributions on the right hand side, interpreting the coefficient on contributions as the effect of interest group money on legislator voting

\footnotetext{
${ }^{4}$ Money transfers between firms and legislators can occur illegally and legally. Illegal transfers of money, undisclosed cash transfers from firms to legislators in exchange for favors and a quid pro quo, are generally considered bribes. These favors could be votes, legislation, oversight of regulatory agencies, or other benefits. The study of explicit bribes, which are often associated with governmental corruption, is outside the scope of this paper.
} 
behavior. The problem with this approach, however, is that contributions are not randomly given; rather they are passed out strategically by firms. This means econometrically that the contributions are correlated with the error term in the regression resulting in biased parameter estimates. To solve this problem they suggest one should find a natural experiment or use instrumental variables. Ansolabehere et al (2003) use the instrumental variable approach. When they run the traditional model without instruments, they get a large positive and statistically significant parameter estimate on contributions, as with previous studies. However, when they use instrumentation and fixed effects procedures, the coefficient switches sign and is not statistically significant. Thus, the increasingly prevalent view amongst academics is that campaign contributions do not buy votes (at least in the United States). ${ }^{5}$

If money does not buy votes, then why do firms contribute? What does money buy? The dominant view is that PAC money buys access_-access to legislators' staffs and to the legislator herself. A legislator's time is valuable and the legislator must decide which firm representatives to meet with. One sorting mechanism, on the margin, is to use campaign contributions. Indeed, Milyo (2002) has likened contributions to Christmas cards and fruit baskets. When two hundred people want to meet with you, whom are you most likely to meet? The person who has been sending you Christmas cards for years or the person who has not contacted you for years? In Milyo's paper, Christmas cards rule the day—not for corruptive reasons, but because they are a token of familiarity, friendship, and collegiality. One of the most cited formal theoretical models of “access" is Austen-Smith (1995). Empirical work on the access hypothesis has largely been in the form of case studies on particular issues, such as farming (Hansen 1991) and trade (Schattschneider 1935). These case studies have found substantial support for the access hypothesis. Note, however, there has been a modicum of statistical work on the subject. Once access is obtained, a firm lobbies — which is the subject of the next subsection of this paper.

In addition, there is a growing literature on the value of political connections to a firm which this paper does not examine. See (Faccio 2004, Fisman 2001, and Hillman et al 1999)

${ }^{5}$ One alternative hypothesis that has been proposed is that money does not buy a vote, but buys a legislator's effort - that is, the legislator is being paid for exerting effort in looking after and/or passing a bill (Baron 1989, Hall and Wayman 1990) 


\section{Information}

Lobbying is generally regarded as the act of an interest group providing information to a legislator and her staff through private or small meetings and communications. Information is thought of broadly, to include facts, knowing or unknowing falsehoods, threats, commitments, or any other kind of

oral or written message that can be transmitted. Academically, lobbying is different from advertising and media campaigns which are very public and often are targeted not directly at the legislator, but rather at her constituents, who subsequently pressure the legislator to adopt a particular position. It is important to note that no money changes hands in lobbying-only information. In this sense, it is quite distinct from vote buying.

The theoretical work on informational lobbying is vast. The canonical model is a principal-agent model where the agent (in this case, the lobbyist) has better information about the effects of a policy or decision than the principal (in this case, the legislator). The lobbyist has private information about the impact of policy, the preferences of constituents, and the technical aspects of policy implementation. The legislator wishes to extract the information so as to make good decisions that will lead to re-election and/or personal ideological congruence. However, the lobbyist is biased and therefore has an incentive to provide biased information to the principal that will result in a favorable policy outcome for the agent.

At its broadest level, theoretical papers that consider asymmetric information can be classified into two branches - information that is verifiable ex post by the principal and information that is not verifiable by the principal. If information is verifiable, then the principal receives information, checks it (or threatens to check it), and then makes policy decisions. A number of models have been constructed with these features, varying the assumptions of preferences and the cost of information verification (de Figueiredo, Spiller, and Urbitztondo 1999, Epstein and O’Halloran 1994, and Austen-Smith 1993). An often cited model is Austen-Smith and Wright's $(1992,1994)$ model of counteractive lobbying. In this model, two interest groups choose simultaneously whether to invest in data collection at exogenous cost. After making this investment and discovering the true state of the world, each group simultaneously decides whether and which legislators to lobby-friends or enemies. The model demonstrates groups 
focus their lobbying on those legislators who are on marginally on the opposite side of the issue from the interest group to try to convince them to switch their votes. An interest group, however, does lobby its allies in order to "counteract” the lobbying of the opponent interest group. Thus, counteractive lobbying occurs. $^{6}$

When information is not verifiable, two types of models are usually employed: where information is costless to acquire and transmit to the principal and where information is costly to acquire and transmit. The former category of models, costless information acquisition and transmission, are generally considered “cheap talk” models. The agent transmits a message to a principal and the principal must assess whether there is any useful information in the message. Although one might believe that such kind of messages are just "hot air" or "cheap talk," Crawford and Sobel (1982) have shown that if the preferences of the principal and agent are sufficiently close, cheap talk can be informative. Since this paper was published, there have been literally thousands of cheap talk models written. One of the most influential recent papers in the area (Battagalini 2002) shows that if there are two orthogonal dimensions to policy outcomes (e.g. Medicare eligibility and Medicare reimbursement rates) and two interest groups (American Hospital Association and American Association of Retired Persons), truthful information revelation can occur. This paper has spawned a renaissance in the cheap talk literature (see Ambrus and Takahashi 2008 for an overview).

A second type of model assumes information is not verifiable but is costly to acquire and/or transmit. Information may be costly to acquire and transmit because the interest group has to put people on the ground, conduct surveys, have meetings, or poll citizens, to name just a few instances of expense. Costly information can have two characteristics- the costs can be exogenously determined or endogenously determined. Exogenous costs means there is a fixed fee for interest groups to acquire and transmit information. These exogenous costs are like participation fees to lobby-exogenously determined fees. Information is transmitted in two main ways in these models. First the observable decision of the interest group whether or not to pay the fee gives the legislator information about the ex

\footnotetext{
${ }^{6}$ There are also models where two biased interest groups invest in obtaining information, but once that information
} 
ante probability distribution of a favorable outcome for the interest group. A second source of information in these models is the decision of the firm to send a message. These models (Lohmann 1993, Grossman and Helpman 2001, and Bennedsen and Feldman 2002) are attractive when the cost to collect or transmit information is a discrete price.

Frequently, however, the firm decides precisely how much money to invest in information collection and transmission. When the firm can choose how much to spend, the information acquisition and lobbying expenditures are endogenously determined. Endogenous cost lobbying models are often called "money burning” models and frequently have signaling properties—-that is the amount the interest group invests in lobbying signals something about the veracity of the information. The challenge for the principal in these models is to establish a lobbying schedule so that the principal obtains truthful information revelation about the state of the world from the interest group (Grossman-Helpman 2001, Potters Van Widen 1992). Under a schedule that induces truthful information revelation, the interest group must spend more money the farther away are its policy preferences relative to the legislator.

What is striking about the literature on lobbying is that there is extremely limited empirical work linking the theory to data. The first and most prevalent approach of statistical empirical work describes how much firms lobby and how they lobby (e.g. Schuler 1996, Schuler et al 2002, Baumgartner and Leech 1998, Leech et al 2005, de Figueiredo 2004). Many, but not all, of these papers rely on data from the federal lobbying disclosure reports mandated in the 1995 Lobbying Disclosure Act. A second category of papers attempt to quantify the effect of lobbying on policy outcomes (de Figueiredo and Silverman 2006, Hedge and Mowery 2008). Finally, there are two papers that attempt to actually test the implications of lobbying models by closely linking formal theory to data analysis. The first is the aforementioned paper (Austen-Smith and Wright 1994) which examines the counteractive lobbying hypothesis using data from the battle over the Supreme Court nomination of Robert Bork in 1987, while the second paper uses state level lobbying data to examine the Grossman-Helpman endogenous cost lobbying models (de Figueiredo and Cameron 2008). Both papers find substantial support for these two

is collected, it enters the public domain. See, for example, Dewatripont and Tirole (1999). 
models in the data.

The area of corporate influence on legislation—whether through contributions, access, or information—has led to advances by economists and political scientists in understanding how interest groups and firms affect policy. This said, corporate influence is not only exercised over legislators. Administrative agencies are another area in which non-market strategy can be effective. The next section addresses this area.

\section{Administrative Agencies}

Because of the breadth of areas over which legislators must consider laws, it is difficult for a single elected body to oversee the details, implementation, and monitoring of the legislation. Elected officials simply do not have the time nor the expertise to engage in all of these activities. Therefore, legislatures delegate these tasks to administrative agencies—or the bureaucracy.

Generally, there are two types of bureaucratic agencies-executive agencies and independent agencies. Executive agencies, such the Department of Housing and Urban Development, report to the executive branch of the government. Independent agencies, such as the Federal Energy Regulatory Commission and the Federal Communications Commission, have a governing board or commission appointed by the President and confirmed by the Senate, but do not report to the President. They are technically independent from elected government, though both the legislature and the executive attempt to influence the agency through funding, influence, public opinion, and various forms of oversight.

Because the legislature delegates the details to the agency, the agency can have substantial power in determining the implementation of the laws. The agency is headed by appointees, but it is staffed with civil service employees who have dedicated their lives to understanding the industry, issue, or area. It is often believed that agencies are more expert, cautious, and long-term policy-sensitive than the legislature.

With this structure, firms have a second opportunity of influencing the contours of agency regulations. As in the legislature, there are two potential ways in which firms influence outcomes in the agencies themselves: through money and through information. As before, the transfer of money from an 
interest group to a regulator to influence policy outcomes is generally considered a bribe and, therefore, is outside the analysis of this paper.

However, information transmission between a firm and agency is not only perfectly legal but actually encouraged to enhance the agency decision-making process. The European Commission, for example, relies upon the substantial amount of information flow from firms for better policy implementation. The staffs of agencies are limited, and they do not have the requisite manpower or resources to effectively generate the necessary quantity or quality of information for good policymaking. Just as the interest groups possess more information than legislators, the interest groups also possess more information than the agency (though the information asymmetry may not be as acute as with legislatures).

In the same way that asymmetric information models are applied to legislatures, they are applied to agencies. However, in this case, the administrative agency is the principal and the interest group is agent. As before, both have biases and the interest group provides information to the regulator. The details of these models need not be repeated here as their effects are the same. ${ }^{7}$

Empirically, there has been an enormous amount written on how interest groups affect agency outcomes. Most of the literature is contained in discursive books that describe (in great detail) individual agencies, their decision-making processes, and the role of interest groups (e.g. Carpenter 2010, Hansen 1991, Stone 1991). Outside of the limited statistical analyses found in these more discursive books, there are a handful of statistical studies of lobbying in agencies. This handful of studies has focused on the amount of lobbying and the organization of lobbying, and has largely not considered the effect of lobbying on agency outcomes (de Figueiredo and Tiller 2001, de Figueiredo and Kim 2004).

\section{Courts}

\footnotetext{
${ }^{7}$ One area of difference is exactly what agencies maximize. While most academics agree that elected politicians maximize some mix of re-election potential, promotion to higher office potential, and ideology, it is unclear exactly what agencies maximize-social welfare, promotion to higher office, ideology, and status are all considered in the regulator's utility function to some extent. Spiller (1990) has argued that regulators also maximize their private sector job prospects after governmental employment.
} 
In many countries, an agency's decision is subject to judicial review. In the United States, the Administrative Procedures Act and the agency's enabling statute outlines the ways in which an agency ruling may be challenged in court. The rule-making could be arbitrary and capricious, the agency may not have jurisdiction on the issue, or the agency may have not followed proper procedures in creating its rules. The arbiters of a legal challenge to an administrative agency rule are judges-judges who are political actors and tend to render decisions in accordance with their own preferences (see, e.g. Segal and Spaeth 1993, Segal 1997, Spiller and Gely 1992; Spiller and Spitzer 1992; Cohen and Spitzer 1994; Tiller 1996; Tiller and Spiller 1999; Marks 1988; McCubbins et al 1994, 1997; Cross and Tiller 1998; Epstein and Knight 1995; de Figueiredo 2005; Revesz 1997: Cross and Tiller 1999, Martin and Quinn 2002, de Figueiredo and Tiller 1996, de Figueiredo et al 2001). ${ }^{8}$ For example, conservative judges may be more pro-business, anti-regulation, or strong property rights than liberal judges. These judge sit in a hierarchy with lower level district judges, middle level appellate judges, and high level Supreme Court justices.

As with agencies, it is generally illegal for members of the appointed judiciary to accept money from litigants. ${ }^{9}$ However, judges can accept information. The theoretical models on the subject largely assume that information is well known and that the judge is exerting effort to protect her decision from override from a higher judicial authority. Empirical models on the subject find similar results. The above-mentioned papers cover these topics in some detail.

What is missing from this literature is the injection of interest groups. A small number of papers have attempted to examine the role of litigants in government litigation. These largely empirical papers find that resource-intensive groups appear to have the advantage in lower courts. Olson (1990), for example, finds that empirically, large groups can use federal district courts to "enforce gains” won in other fora. Similarly, Songer and Sheehan (1992) find that in the United States Courts of Appeals “upperdog litigants win much more frequently.” Overall, though, outside of the legal literature, there has been little work done on role of litigants and the government in corporate political strategy.

\footnotetext{
${ }^{8}$ There is a literature emanating from Law and Economics assuming that judges "find the truth." These papers, however, model civil litigation where one firm sues another. For a literature review of this literature, see Hay and Spier (2004).
} 


\section{Integration of the Venues}

The legislative aspects to this field of study came to be known as "Pivotal Politics" (Krehbiel 1998). The general structure of these models is well-defined decision-maker preferences, a clear sequence of moves amongst actors, a well-specified policy-space, and a clear set of rules by which one actor can select or overturn policy. Taken together, these will create pivot points which will determine each actor's discretion and the final win set for policy.

With these building blocks, scholars turned their efforts to understanding how institutions interact with each other. This literature began with explaining how institutions, as strategic actors, created and protected the policies they generated (in the absence of interest groups). The first papers in this area explored the relationship between legislatures and agencies. Marks (1988) and McNollgast (1989) developed a set of spatial preference models where a legislature (principal) delegated the implementation of policy to an agency (agent) with different preferences for policy outcomes. As in most principal-agent models, costly monitoring by the principal leads to an equilibrium where the agent has some discretion in decision-making. The principal is required to make trade-offs in investing in monitoring versus discretion by the agency. A steady stream of models in this area explains the details of this principal-agent relationship (McCubbins and Schwartz 1984, McNollgast 1989, Banks and Weingast 1992, Ferejohn and Shipan 1989). These legislature-agency models were then followed quickly by legislature-court and agency-court models with the same principal agent flavor - the principal attempting to secure its policy preferences by monitoring the agent while the agent attempts to exercise discretion in the presence of costly monitoring. (Spiller 1992, Spiller and Spitzer 1992, McNollgast 1994, Tiller 1998, Tiller and Spiller 1999, Canes-Wrone 2003, Eskridge 1991).

It is within this context that recent work has begun to insert interest groups and firms into the mix. In the first set of papers, the interest groups have private information, and this private information is passed on to a given institution (agency) who then bargains with other institutions (legislature). The

\footnotetext{
${ }^{9}$ Klerman (2007) notes an exception to this case in England in the 1800s where judges received fees from plaintiffs!
} 
tension occurs in these models because of the information advantage the interest group has over the agency and the agency has over the legislature. In all of these papers, information is assumed to be verifiable ex post (de Figueiredo, Spiller, Urbitztondo 1999, Epstein and OHalloran 1995, Boehmke et al 2006). Additional models introduced courts into the multi-institutional mix (Rubin, Curran and Curran 1999, Caldeira and Wright 1998, McGuire and Caldeira 1993, Olson 1990).

A second set of papers loosens the constraint that the firm can affect only one venue. Rather, the firm chooses which institution to influence, and then the institutions play a principal-agent game. Advances along these lines are in their infancy at best.. The most recent scholarship in multi-institution games with interest groups that try to influence multiple venues relies largely on vote-buying models. De Figueiredo and de Figueiredo (2002) examine how policy is changed in a vote-buying model when the interest group can choose to invest in influencing a regulator or save its money and invest in building a better court case against the agency. Holburn and Vanden Bergh (2004) also build a vote-buying model that allows the firm to influence policy outcomes by either bribing politicians or bribing regulators. Despite the fact that it well-known that interest groups endogenously choose venues to lobby, there are, to date, no papers of which I am aware that incorporate a multi-institution model with non-verifiable information and endogenous choice of venue by interest group.

\section{Research Questions}

So where do we go from here? Four areas seem to have the prospect for scholars to create a sustainable research agenda. ${ }^{10}$ First, there is a need for better theories of how interest group behavior in multiple institutions affects policy outcomes. Figure 2 illustrates this opening. The first dimension of the table shows the institutional breadth of formal theoretical and empirical work to date. The second dimension examines whether the theoretical and empirical models explore money or information. What is evident from the table is that informational models that include multiple institutions and interest groups are both lacking from a theoretical perspective and empirical perspective. (In addition, there is no 
empirical work on vote-buying models that examines multiple institutions and interest groups with venue choice.) There are at least two obvious ways to explore this question. The first is to model the interactions between two competing interest groups. The second is to exploit endogenous cost lobbying models that allow interest groups to choose their level and mix of lobbying expenditures across venues.

A second opening for research is to seriously test theoretical models. This pursuit could follow one of two paths. The first path is to develop new theoretical features in a discursive model that takes seriously the multi-institutional approach that interest groups pursue. From this framework, one would develop testable implications for which new datasets could be used. A second path is to take the current theoretical models, develop testable implications, and bring data and solid empirical methods to the endeavor. This might involve simplifying the current formal models so that they can be tested, or developing additional mathematical apparatus so as to conform to the general structure of the data available. I discuss this first path further in the next section with the sketch of a discursive model that could be the departure point for such a project.

The third avenue for research is improving empirical measures and data. There is a trend in management strategy, economics, and political science away from traditional datasets and toward more creative datasets. For example, the data from the federal government or states on political contributions or the lobbying expenditure data from the federal Lobbying Disclosure Act of 1995 are now considered common sources of data. The researcher who is to make an impact must discover and develop alternative sources of data. For example, datasets on firm bureaucratic lobbying can now be created from federal agencies' disclosure reports. In addition, states keep a variety of data on lobbying and information disclosure that can be a useful source for empirical work (Gray et al 2002, de Figueiredo 2004, de Figueiredo and Cameron 2008).

Another possibility in data development is to integrate different datasets that proxy for political action across multiple venues. For example, the data from the Lobbying Disclosure Act of 1995 quantifies corporate lobbying in legislatures. Comments and ex parte contacts by firms in federal

\footnotetext{
${ }^{10}$ See Hillman et al (2004) for an alternative review of the literature.
} 
agencies quantify lobbying by these same firms in the bureaucracy. Finally, the PACER database quantifies the degree of information being transmitted to courts through filings of briefs and motions. Some of these datasets are not only novel and innovative, but integrating these datasets will allow the researcher to test hypotheses about lobbying across multiple institutions. In addition, one should look for natural experiments or exogenous variation in data. States and countries vary in their rules, their structures, and their financing —all leading to sources of variation that can be exploited by researchers.

The final area for research and perhaps the area where promising young researchers can make the biggest impact in corporate political strategy is linking firm corporate political strategy to policy outcomes to firm market performance. Researchers have largely been content to date to link the first two areas or the second two areas. However, I am aware of only one theoretical paper and no empirical work that integrates all three areas (Baron 1999). This is truly a promising area of research. The challenge to overcome in pursuing this research is controlling for the endogeneity of right hand side variables throughout potential empirical tests.

\section{Outline of a Theory}

In this section I attempt to outline a theoretical construct for multiple venue lobbying that might serve as the basis for the second area for research. This is very preliminary, but it could be a useful guide for thinking about these issues.

We begin the analysis with an understanding of veto points or pivotal players (Cameron 2002, Krehbiel 1998). In the federal government and all state governments, except Nebraska, a House and a Senate, and an executive (the president or the governor) must each approve any new legislation. In addition, within the House and Senate, there are multiple veto points in the form of committeessubstantive area committees (e.g. Commerce), procedural committees (e.g. Rules), and conference committees (Weingast and Marshall 1988, Shepsle and Weingast 1987) which all have substantial power. Thus, in creating legislation, there are many veto points that must be overcome.

Inside of regulatory agencies, there also exist veto points or points of substantial influence. There 
are three main levels of decision-making within agencies (de Figueiredo and Kim 2004). The first level is comprised of the civil servants who are able to influence (though not veto) the ultimate rule that is passed through agenda-setting, delay, and recommendations. For instance, in pharmaceutical drugs, it is known that Food and Drug Administration employees tend to slow the approval process of a company's drug if that company engages in conduct of which the FDA disapproves. With a blockbuster drug generating one million dollars in revenue each day it is on the market, even one week of delay can be extremely costly to the company (Economist 1998). The second level in the agency is comprised of the personal staffs of the political appointees. These individuals influence the outcome through control of access to and advising of the commissioners. Like the civil servants, these staffers have no veto, but they do have influence. The final level is the political appointee, known as a commissioner or agency head, who is the ultimate policymaker in administrative agencies. The commissioner(s) has the power to create rules; she retains the true veto power.

Finally, judges who preside over courts and have preferences over policy will arbitrate the law in such a way to conform to their ideologies. In all, the judicial branch has between one and three veto points within it (depending upon the type of case)—-the district court judge, the appellate court 3-judge panel, and the Supreme Court. From a practical standpoint, the Supreme Court will rarely hear cases, as less than 100 cases annually are granted cert by the Court.

We can now define three regularities about the probability of a firm obtaining favorable policy. First, with this policy-making process, certain institutions are more receptive to policy change than others, holding all else constant. Obtaining statutes to change policy can be difficult because of the number of hurdles that must be overcome; for the same reason, courts are a place where favorable policy is easier to obtain; agencies are in the intermediate range.

Second, because policy pursuit in multiple fora is not a mutually exclusive activity, a probability enhancing strategy can be to pursue policy in multiple fora. We can characterize the probability of this outcome using Bayes Rule: 


$$
P(L \text { u R u C })=P(L)+P(R)+P(C)-P(R L)-P(C R)-P(L C)-P(L R C)
$$

where $\mathrm{P}(\mathrm{L})$ is the probability of passing new policy in the legislature, $\mathrm{P}(\mathrm{R})$ is the probability of passing policy in the agency, and $\mathrm{P}(\mathrm{C})$ is the probability of passing new policy in the court. Note, with such a characterization of the multiple forum strategy, we know that the probability of obtaining the policy in any one institution sets a lower bound on the probability of obtain policy in multiple forums. In fact, this formula will allow us to consider the range of possibilities. Assume there is a 0.8 probaility of getting policy through any one veto gate within an institution. If a firm is willing to accept policy generation from any one institution, then a multiple forum lobbying effort will yield a 87\% chance of obtaining favorable policy. If on the other hand, a firm seeks policy of the most durable form, where all three institutions must vote or decide in the affirmative to a policy change, then the probability of success for the firm is only $8.5 \%$, despite the very favorable odds of getting through any one veto gate.

A final item to note is the differential probabilities of success in playing offense v. playing defense. Playing “tough" offense (attempting to make it through all the veto points) is inherently a more difficult job that playing defense. Because the probability of being successful in a defensive posture is the complement of being successful in an offensive posture, one need only to stop the policy at any one veto point to stop the policy altogether. Thus, it is not surprising that the status quo tends to be very sticky and changes to the status quo fleeting.

If the probability of obtaining policy can differ so much across institutions, then why would a firm ever seek policy through an institution where the probability of a favorable outcome is low? The answer lies in the durability and scope of the outcome. When Congress creates policy it has nationwide jurisdiction and enforcement. While agencies can influence the shape of legislation, they cannot overturn it; courts also have an ability to overturn legislation, but only on constitutional grounds. Given the number of veto points within Congress, it is not easy to change a given law. This suggests that there is a wide scope and good amount of durability in congressional legislation.

Agencies also create rules that can have national, regional, or firm-specific impact. Unlike 
Congress, administrative agencies can be subjected to review and change, by the Executive, the Congress, and the Courts (Weingast and Moran, 1983). The durability of these agency rules is questionable, however, because they can be changed relatively quickly, without alterations in the wording of the governing statute or the procedures of the agency. For example, the Carter Administration, through the Department of Health and Human Services (HHS), promulgated a new regulation that permitted the nondirective counseling of pregnant women at federally-funded health clinics in their various health options, including abortion. After the Reagan Administration took office, HHS imposed a restriction on federally funded counseling that made it illegal for counselors to mention abortion as a health or family planning option for these same pregnant women. In February 1993, shortly after President Clinton took office, an interim rule took effect that restored the ability of counselors at federally-funded facilities to discuss all options related to a woman's pregnancy, including abortion (explicitly). All of this occurred without changes to statute. Thus, while agency rule-making has the force of law, the durability of agency rulemaking is subjected to outside actors, such as the president, who have little oversight and can change policy at a whim.

Finally, courts “create” policy through judicial rulings. Depending on the level of the court and its jurisdiction, the scope of the ruling will usually have force over narrow geographical boundaries and over a specific case or set of cases. One important aspect to courts, though, is that because the judiciary adheres to common law and doctrinal principles, judges have few checks and balances to monitor their behavior and insure adherence to stare decisis. In essence, judges can claim that the current case is "unique” in many respects, and that general principles of law do not hold in this particular case, and therefore rule however they wish (Tiller and Spiller 1999). In this sense, judicial precedent is perhaps the least durable aspect to economic rulemaking.

We can now begin to understand the institutions of economic regulation. Each institution has a different number of veto points, or cost, of obtaining policy. Each institution has a different scope of its rulemaking. And each institution has a different durability of policy enacted.

Figure 3 summarizes our discussion to this point and outlines the probability, cost, scope, and 
durability of policy enacted by each of these institutions. What becomes clear is that there are trade-offs in seeking policy in different institutions.

\section{***INSERT FIGURE 3 ABOUT HERE***}

To this point we have established two main principles of political institutions. First, there are multiple institutions that can create policy, and these institutions move, to a first approximation, sequentially. Second, the probability, cost, scope, and durability of policy enactment differ substantially across these institutions. With these two principles, we can examine how firms attempt to influence policy outcomes to their advantage.

To derive a set of testable hypotheses, let us begin by deriving a set of predictions directly related to the institutions. The above discussion and Figure 3 suggests that offensive lobbying strategies can be characterized as follows:

H1a: Holding all else constant, offensive interest groups will pursue their interests in more policy-durable institutions.

H1b: Holding all else constant, offensive interest groups will be less likely to pursue their interests the greater the number of veto points in the institution.

Defensive interest groups also behave strategically (de Figueiredo and de Figueiredo, 2002). They recognize that they have better prospects of defending the status quo in institutions with more veto points. This is attractive because they may not have to expend many resources to defend the status quo at only one point, or if they do, they can target all of their resources at a single veto point (Groseclose and Snyder, 1996). But sometimes, even defense is elusive. If ideology and sentiments run strong in Congress, it may be difficult to slow the process of policy-making there. One strategy defensive firms can employ, though, is to support a version of the new policy in a different, less policy-durable institution. ${ }^{11}$ This occurs because the defense, recognizing the policy may pass in a very durable form (in Congress), chooses to concede the policy temporarily, but seeks an institution where the policy implementation will 
be less durable. The lower durability gives the defensive interest group an opportunity to change or circumvent the policy in the future.

For example, suppose the Sierra Club wishes to prevent an environmentally lax law from taking effect. Seeing that it is the predisposition of Congress to pass such a law, the Sierra Club will go to the EPA and declare it will not challenge the relaxation of pollution emission standards. In doing this, industry obtains its policy goal, at least temporarily, and the Sierra Club obtains low policy durability to challenge another day. The question then arises as to why industry does not convince Congress to pass the law as well. In fact, the actions of the EPA lowers the incentive of Congress to engage in the costly act of legislating. We see this behavior repeatedly in the regulation of business. This leads us to our second hypothesis:

H2: The higher the probability of passage of a rule in a policy-durable institution, the more likely opposing (defensive) interest groups will not oppose the same or a more diluted policy position in policy non-durable institutions to disincentivize the policy-durable institution from acting.

Hypotheses 1 and 2 assume that groups must choose between institutions for policy creation. In fact, there are cases when political action is actually complementary. That is, corporate political activity in Congress actually enhances the value of lobbying at the agency. Congress applies pressure to the agency, in the form of hearings, oversight, and funding, to encourage it to act in a certain way, as it did the initial UPS example. This congressional lobbying by firms catalyzing this pressure actually enhances the value of that firm's lobbying at the agency. Likewise, lobbying the agency with excellent information may enhance the value of litigation effort, as the court relies on the factual record from the agency proceedings to guide the court's decision-making (Strauss et al 1995). Thus, in the presence of complementarity, we expect corporate political activity to increase in multiple forums.

H4: As the complementarity of political effort across institutions increases, the breadth of political effort across institutions will increase.

\footnotetext{
${ }^{11}$ de Figueiredo (2009) describes this within the Congress in a model and empirical test between committees.
} 
We can develop an even more robust theory of corporate political activity by considering how policy characteristics will affect the market activity of firms. For example, consider the result of policy on corporate investment. The imputed risk-adjusted return on investment decreases as the uncertainty increases. In particular, if a policy is delivered that can be easily overturned, then the risk level of the firm's investment increases because the asset may have much lower value in the new environment. Thus, durable policies convey an advantage to investment because of their certainty and lack of flexibility. Nondurable policy, on the other hand, leaves the long-term much more opaque. This, in turn, has an impact on investment.

H5: Policies passed by non-durable policy institutions will result in less long-term investment than the same policies passed by policy-durable institutions.

While the theory to this point has included all the major political institutions and interest groups, it has tended to be U.S.-centric. However, the framework introduced in this paper is, with modification, actually more generalizable. One of the most obvious differences across countries is the design of the legislature_-presidential v. parliamentary systems. There are many forms of parliamentary system, but in some respects they possess a number of common aspects: the ruling party is the one (or coalition) with the most seats in the legislature; there is no independent executive branch; there is a vote of confidence procedure to determine the potential for early elections; administrative agencies often wield limited power; courts deal primarily in issues of private law rather than public law.

What is interesting about parliamentary systems is that policies passed within a government's time in office tend to have high durability. However, policies can be quickly reversed at the change of a government because the government acts, to a rough approximation, as a unitary actor. This then means that parliamentary systems have strong short-term durability but have much lower long-term durability compared to presidential systems. With this as background, hypotheses can be generated for different types of parliamentary systems. Once we can characterize the institutions and sequence of play, veto points, policy-durability, and policy scope of an institution, firm behavior can be articulated. 


\section{Concluding Thoughts}

Non-market strategy is now a well-established field in strategic management. It covers many topics including international institutions, political institutions, the media, activism, corporate social responsibility and sustainability, ethics, and market failures. In the subfield of corporate political strategy, substantial advances have been made by economists, political scientists, and management scholars. This said, there are a number of openings in the literature that will yield fruitful long-term research agendas. In particular, linking theory to data more tightly, developing multi-forum theories of political action, and linking, in a rigorous way, non-market strategies to policy outcomes to market performance, will likely prove to be where the next major advances in the field are. Scholars will do well to focus their efforts on these high profile topics. 


\section{References}

Ambrus, Attila, and Satoru Takahashi (2008). “Multi-sender cheap talk with restricted state space,” Harvard University Department of Economics Working Paper.

Ansolabehere, Stephen D., John M. de Figueiredo, and James M. Snyder (2003). "Why Is There So Little Money in U.S. Politics?” Journal of Economic Perspectives 17(1) 105-130.

Austen-Smith, David (1993). "Information and Influence: Lobbying for Agendas and Votes.” American Journal of Political Science 37: 799-834

Austen-Smith, David (1995). “Campaign Contributions and Access.” American Political Science Review 89: 566-581.

Austen-Smith, David, and John R. Wright (1992). “Competitive Lobbying for a Legislator’s Vote,” Social Choice and Welfare 9: 229-257.

Austen-Smith, David, and John R. Wright (1994). “Counteractive Lobbying,” American Journal of Political Science, 38: 25-44.

Banks, Jeffrey S. and Barry R. Weingast (1992). "The Political Control of Bureaucracies under Asymmetric Information.” American Journal of Political Science 36: 509-524.

Baron, David P. (1989). “Service Induced Campaign Contributions and Electoral Equilibrium,” Quarterly Journal of Economics 104(1): 45-72.

Baron, David P. (1999). "Integrated Market and Nonmarket Strategies in Client and Interest Group Politics,” Business and Politics 1(1): 7-34.

Baron, David P. (2002). Business and Its Environment, 4 th ed. Prentice Hall: New York.

Battaglini, Marco (2002). "Multiple Referrals and Multidimensional Cheap Talk,” Econometrica 70(4): 1379-1401.

Baumgartner, Frank, and Beth Leech (1998). Basic Interests: The Importance of Groups in Politics and Political Science. Princeton University Press: Princeton, NJ.

Becker, Gary S. (1983). “A Theory of Competition Among Pressure Groups for Political Influence.” Quarterly Journal of Economics 98:3 371-400.

Bell Aerospace Co. v. National Labor Relations Board (1974). Supreme Court of the United States 416 U.S. 267.

Bennedsen, Morten, and Sven Feldmann (2002). “Lobbying Legislatures,” Journal of Political Economy 110(4): 919-948.

Besley, Timothy, and Stephen Coate (2001). “Lobbying and Welfare in a Representative Democracy,” Review of Economic Studies 68(1): 67-82.

Boehmke, Frederick, Sean Gailmard, and John Patty (2006). "Whose Ear (or Arm) to Bend? Lobbying and Venue Choice,” Quarterly Journal of Political Science. 
Caldeira, Gregory A., and John R. Wright (1998). "Lobbying for Justice: Organized Interests, Supreme Court Nominations, and United States Senate,” American Journal of Political Science 42: 499-523.

Chevron, U.S. A., Inc. v. Natural Resources Defense Council (1984). Supreme Court of the United States, 486 U.S. 1227.

Cameron, Charles M. (2000). Veto Bargaining: Presidents and the Politics of Negative Power.

Cambridge: Cambridge University Press.

Canes-Wrone, Brandice. 2003. "Bureaucratic Decisions and the Composition of the Lower Courts." American Journal of Political Science 47(2): 205-214.

Carpenter, Daniel (2010). Reputation and Power: Organizational Image and Pharmaceutical Regulation at the FDA. Princeton University Press: Princeton, NJ.

Crawford, V., and J. Sobel. 1982. “Strategic Information Transmission.” Econometrica, 50(6): 14311451.

Cross, Frank B. and Emerson H. Tiller (1998). “Judicial Partisanship and Obedience to Legal Doctrine: Whistleblowing on the Federal Courts of Appeal.” Yale Law Journal 107: 2155-2176.

de Figueiredo, John M. (2004). “The Timing of Lobbying,” NBER Working Paper \#10588

de Figueiredo, John M (2005). "Strategic Plaintiffs and Ideological Judges in Telecommunications Litigation,” Journal of Law, Economics and Organization, forthcoming.

de Figueiredo, John M. (2009). “Committee Jurisdiction, Congressional Behavior, and Policy Outcomes,” UCLA Working Paper.

de Figueiredo, John M., and Charles M. Cameron (2008). Endogenous Cost Lobbying: Theory and Evidence,” UCLA Working Paper.

de Figueiredo, John M., and Rui J. de Figueiredo, Jr. (2002). “The Allocation of Resources by Interest Groups: Lobbying, Litigation, and Administrative Regulation,” Business and Politics 4(2): 161-181.

de Figueiredo, J. M., G.Gryski, E. H. Tiller, and G. Zuk (2000). "Congress and the Political Expansion of the U.S. District Courts,” American Law and Economics Review, 2(1): 107-125.

de Figueiredo, J. M., and J. K. Kim (2004) "When do Firms Hire Lobbyists? The Organization of Lobbying at the Federal Communications Commission,” Industrial and Corporate Change 13(6): 883900.

de Figueiredo, J. M., and B. S. Silverman (2006). “Academic Earmarks and the Returns to Lobbying,” Journal of Law and Economics, 49(2) (October), 597-626.

de Figueiredo, J. M., and E. H. Tiller (1996). "Congressional Control of the Courts: A Theoretical and Empirical Analysis of Expansion of the Federal Judiciary,” Journal of Law and Economics 39(2): 435462.

de Figueiredo, John M., and Emerson H. Tiller (2001). “The Structure and Conduct of Lobbying: An 
Empirical Analysis of Corporate Lobbying at the Federal Communications Commission,” Journal of Economics and Management Strategy 10(1): 91-122.

de Figueiredo, Rui J., Pablo Spiller, and Santiago Urbitztondo (1999). “An Informational Perspective on Administrative Procedures,” Journal of Law, Economics, and Organization 15(1): 283-305.

Dewatripont, Mathias, and Jean Tirole (1999). “Advocates,” Journal of Political Economy 107: 1-39.

Economist (1998). “The Pharmaceutical Industry,” The Economist, 21 Feb 1998, pp. 3-18.

Epstein, David, and Sharyn O’Halloran (1994). “Administrative Procedures, Information, and Agency Discretion,” American Journal of Political Science 38: 697-722.

Epstein, David, and Sharyn O’Halloran (1995). “A Theory of Strategic Oversight: Congress, Lobbyists, and the Bureaucracy,” Journal of Law, Economics and Organization 11: 227 - 55.

Eskridge, William D. (1991). “Overriding Supreme Court Statutory Interpretation Decisions,” Yale Law Journal 101: 331.

Executive Office of the President (2008). Budget of the United States Government. Fiscal Year 2009. Government Printing Office: Washington, DC.

Faccio, Mara (2004). “Politically Connected Firms,” American Economic Review 96(1): 369-386.

Ferejohn, John A., and Charles F. Shipan (1989). “Congressional Influence on the Bureaucracy,” Journal of Law, Economics, and Organization 6: 1-27.

Fisman, Raymond (2001). "Estimating the Value of Political Connections," American Economic Review 91(4): 1103-1115.

Goldberg, Penelope, and Giovanni Maggi. 1999. Protection for Sale: An Empirical Investigation,” American Economic Review 89: 1135-1155.

Gray, Virginia, David Lowery, Todd McNoldy, Adam Newmark, and Jennifer Wolak. 2002. "Much of Politics is Still Local: Multi-State Lobbying in State Interest Communities." Legislative Studies Quarterly 27(4):527-556.

Groseclose, Timothy, and James Snyder (1996). “Buying Supermajorities,” American Political Science Review, 90:303-15.

Grossman, Gene and Elhanan Helpman. 1994. “Protection for Sale,” American Economic Review 84(4): 833-850.

Grossman, Gene and Elhanan Helpman. 2001. Special Interest Politics. Cambridge, MA: The MIT Press.

Hall, Richard L, and Frank W. Wayman (1990). "Buying Time: Moneyed Interests and the Mobilization of Bias in Congressional Committees,” American Political Science Review 84: 797-820.

Hansen, John Mark (1991). Gaining Access: Congress and the Farm Lobby, 1919-1981. Chicago: University of Chicago Press. 
Hay, Bruce L., and Kathryn E. Spier (2004). “Litigation and Settlement,” in the ed. Peter Newman, New Palgrave Dictionary of Economics and the Law. Palgrave MacMillan: New York.

Hedge, Deepak and David Mowery (2008). "Politics and Funding in the U.S. Biomedical Research System," Science 322.

Hillman, Amy J., Gerald D. Keim \& Douglas A. Schuler. 2004. "Corporate Political Strategies: A Review and Research Agenda." Journal of Management 837-857.

Hillman, Amy J., Asghar Zardkoohi, and Leonard Bierman (1999). "Corporate Political Strategies and Firm Performance: Indications of Firm-Specific Benefits from Personal Service in the U.S.

Government,” Strategic Management Journal 20: 67-81.

Holburn, Guy, and Richard Vanden Bergh (2004). "Influencing Agencies Through Pivotal Institutions," Journal of Law, Economics, and Organization 20(2): 458-483.

Klerman, Daniel (2007). “Jurisdictional Competition and the Evolution of Common Law,” University of Chicago Law Review 74:1179.

Krehbiel, Keith (1998). Pivotal Politics: A Theory of U.S. Lawmaking. Chicago: University of Chicago Press.

Leech, Beth L., Baumgartner, Frank R., Timothy La Pira, and Nicholas A. Semanko. 2005. "Drawing Lobbyists to Washington: Government Activity and Interest-Group Mobilization.” Political Research Quarterly 58, 1 (March 2005): 19-30.

Lohmann, Suzanne. 1993. “A Signaling Model of Informative and Manipulative Political Action,” American Political Science Review 87: 319-333.

Marks, Brian (1988). “A Model of Judicial Influence on Congressional Policymaking: Grove City College v. Bell,” Political Science Working Paper, P-88-7, The Hoover Institution, Stanford University.

Martin, Andrew, and Kevin M. Quinn (2002). "Dynamic Ideal Point Estimation via Markov Chain Monte Carlo for U.S. Supreme Court, 1953-1999,” Political Analysis 10: 134-153.

McCubbins, Mathew D., Roger Noll and Barry R. Weingast (1987). “Administrative Procedures as Instruments of Political Control.” Journal of Law, Economics, and Organization 3: 243-277.

McCubbins, Mathew D., Roger Noll and Barry R. Weingast (1989). "Structure and Process, Politics and Policy: Administrative Arrangements and the Political Control of Agencies.” Virginia Law Review 75: 431-482.

McCubbins, Mathew D., Roger Noll and Barry R. Weingast (1994). "Legislative Intent: The Use of Positive Political Theory in Statutory Interpretation.” Law and Contemporary Problems 57: 3-37.

McCubbins, Mathew D., and Thomas Schwartz (1984). "Congressional Oversight Overlooked: Police Patrols v. Fire Alarms,” American Journal of Political Science, 29: 721-749.

McGuire, Kevin T., and Gregory A. Caldeira (1993). "Lawyers, Organized Interests, and the Law of Obscenity: Agenda Setting in the Supreme Court,” American Political Science Review 87: 717-726. 
Milyo, Jeff (2002). "Bribes and Fruit Baskets: What Does the Link Between PAC Contributions and Lobbying Mean?” Business and Politics 4(2): 157-160.

Potters, Jan and Frans Van Winden. 1992. “Lobbying and Asymmetric Information,” Public Choice 74: 269-92.

Revesz, Richard (1997). “Environmental Regulation, Ideology and the D.C. Circuit,” Virginia Law Review: 1717.

Olson, Susan (1990). “Interest Group Litigation in Federal District Court: Beyond Political Disadvantage Theory,” Journal of Politics 52: 854-882.

Peltzman, Samuel (1976). “Toward a More General Theory of Regulation.” Journal of Law and Economics 19: 211-240.

Rubin, Paul H., Christopher Curran, and John F. Curran (1999). "Litigation versus Legislation: Forum Shopping by Rent-Seekers,” Department of Economics Working Paper, Emory University.

Salop, S., and D. Scheffman (1983). “Raising Rivals’ Costs,” American Economic Review 73: 267-271.

Schattschneider, E.E. (1935). Politics, pressures, and tariffs. Prentice Hall: New York.

Schuck, Peter H., and Donald E. Elliott (1990). “To the Chevron Station: An Empirical Study of Federal Administrative Law,” Duke Law Journal: 984-1084.

Schuler, Douglas (1996). "Corporate political strategy and foreign competition: The case of the steel industry,” Academy of Management Journal 45: 659-672.

Schuler, Douglas, Kathy Rehbein, and R. Cramer (2002). "Pursuing Strategic Advantage through Political Means,” Academy of Management Journal 45: 659-672.

Segal, Jeffrey A. (1997). "Separation-of-Powers Games in the Positive Theory of Congress and the Courts," American Political Science Review 91: 28-44.

Segal, Jeffery A., and Harold J. Spaeth (1993). The Supreme Court and the Attitudinal Model. Cambridge: Cambridge University Press.

Shepsle, Kenneth A. and Barry R. Weingast. 1987. "The Institutional Foundations of Committee Power.” American Political Science Review. 81:1. 85-104

Snyder, James (1990). "Campaign Contributions as Investments: The U.S. House of Representatives, 1980-1986,” Journal of Political Economy 98: 1195-1227.

Snyder, James (1991). “On Buying Legislatures,” Economics and Politics 3: 93-109.

Snyder, James (1992). “Long-Term Investing in Politicians; Or, Give Early, Give Often” Journal of Law \& Economics 35: 15-43.

Songer, Donald R., and Reginald S. Sheehan (1992). "Who Wins on Appeal? Upperdogs and Underdogs in the United States Courts of Appeals,” American Journal of Political Science 36: 235-258. 
Spiller, Pablo T. (1990). "Politicians, Interest Groups, and Regulators: A Multiple-Principals Agency Theory of Regulation, or “Let Them Be Bribed,” Journal of Law and Economics 33(1): 65-101.

Spiller, Pablo T (1992). “Agency Discretion Under Judicial Review.” Mathematical and Computer Modelling 16: 185.

Spiller, Pablo T. and Rafael Gely (1992). "Congressional Control of Judicial Independence: The Determinants of U.S. Supreme Court Labor-Relations Decisions, 1949-1988.” Rand Journal of Economics 23: 463-492.

Spiller, Pablo T. and Matthew Spitzer (1992). “Judicial Choice of Legal Doctrines.” Journal of Law, Economics and Organization 8: 8-46.

Spulber, Daniel (1994). “Economic Analysis and Management Strategy,” Journal of Economics and Management Strategy 3(2): 355-406.

Stigler, George J. (1971). “The Theory of Economic Regulation.” Bell Journal of Economics and Management Science 2:3-21.

Stone, Richard D. (1991). The Interstate Commerce Commission and the Railroad Industry. Praeger Publishing: New York.

Stratmann, Thomas (1992). "Are Contributors Rational? Untangling Strategies of Political Action Committees,” Journal of Political Economy 100: 647-664.

Stratmann, Thomas (1998). “The market for congressional votes: Is timing of contributions everything?” Journal of Law \& Economics, 41:85-113.

Strauss, Peter L., Todd Rakoff, Roy A. Schotland, and Cynthia R. Farina (1995). Administrative Law Cases and Comments. Westbury, New York: The Foundation Press.

Tiller, Emerson H. (1998) “Controlling Policy by Controlling Process: Judicial Influence on Regulatory Decision Making.” Journal of Law, Economics and Organization 14: 114-135.

Tiller, Emerson H. and Frank B. Cross. (1999) "A Modest Proposal for Improving American Justice," Columbia Law Review 99: 215-234.

Tiller, Emerson H. and Pablo T. Spiller (1999). "Strategic Instruments: Legal Structure and Political Games in Administrative Law,” Journal of Law, Economics and Organization 15.

United States v. Mead Corporation (2001). Supreme Court of the United States, 121 S. Ct. 2164.

Weingast, B.W. \& Marshall, W. (1988). "The Industrial Organization of Congress; or, Why Legislatures, Like Firms, Are Not Organized as Markets”. Journal of Political Economy, 96 (1), 132-163

Weingast, B. \& Moran, M. (1983). "Bureaucratic discretion or congressional control: Regulatory policymaking by the Federal Trade Commission.” Journal of Political Economy, 91 (October), 765-800 


\section{Figure 1: Corporate Political Influence}

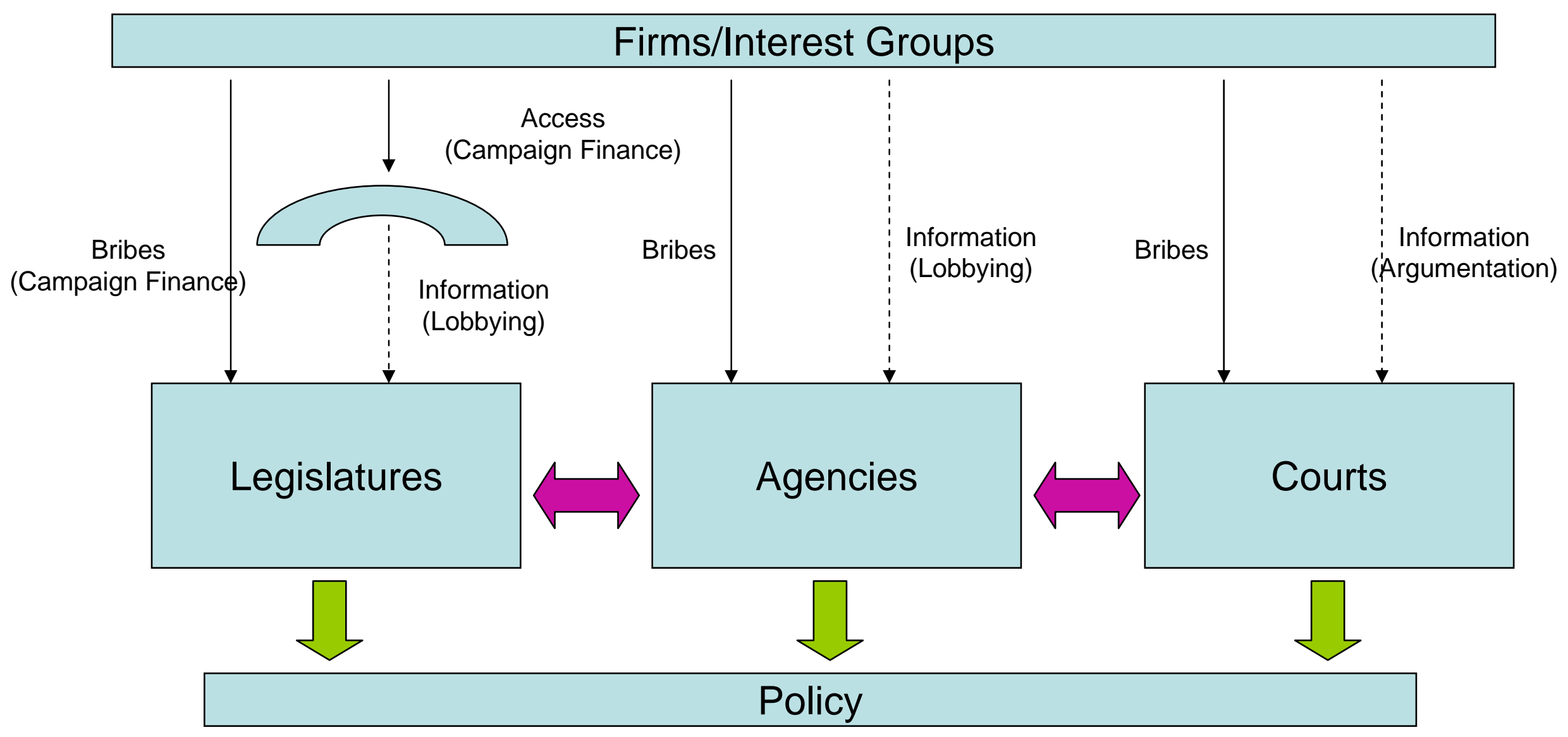




\section{Figure 2: Interest Groups and Research Gaps}

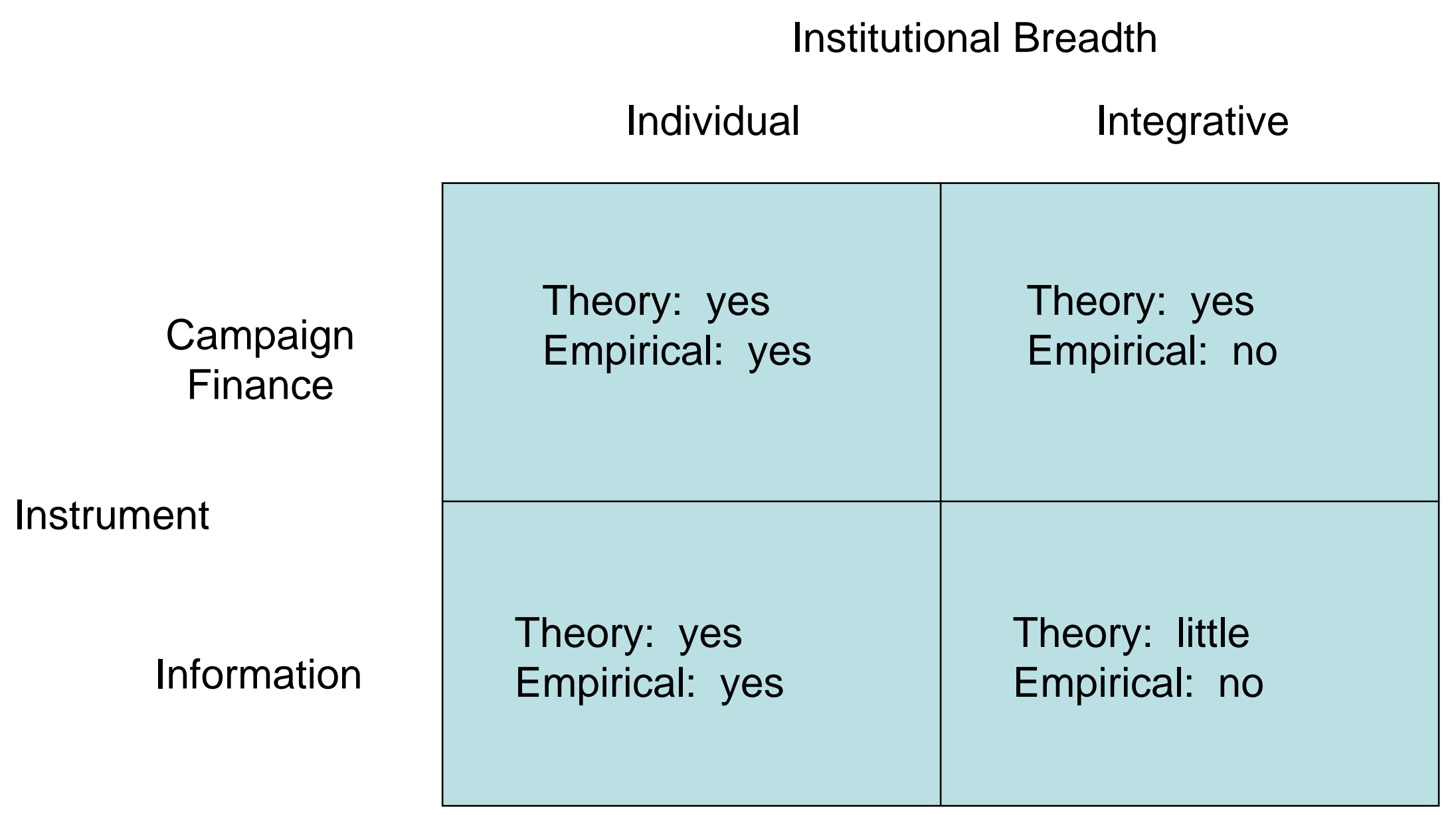




\section{Figure 3: Understanding Multi-Forum Action}

\begin{tabular}{|c|c|c|c|c|c|}
\hline $\begin{array}{c}\text { Instrument of } \\
\text { Change }\end{array}$ & Cost & $\begin{array}{c}\text { Probability of } \\
\text { Passage }\end{array}$ & $\begin{array}{c}\text { Veto } \\
\text { Points }\end{array}$ & Durability & Breadth \\
\hline Legislation & High & Low & Many & High & High \\
\hline Regulation & Moderate & Moderate & Low & Low & High \\
\hline Litigation & Low & High & Low & Moderate & Low-Mod \\
\hline
\end{tabular}

